\title{
Seroprevalence of Antibodies against Porcine Teschovirus 1 in Lithuania
}

\author{
V. SEREIKA, R. LELESIUS, D. ZIENIUS \\ Department of Virology, Veterinary Institute of Lithuanian Veterinary Academy, Kaisiadorys, Lithuania \\ Received September 19, 2005 \\ Accepted April 13, 2006
}

\begin{abstract}
Sereika V., R. Lelesius, D. Zienius: Seroprevalence of Antibodies against Porcine Teschovirus 1 in Lithuania. Acta Vet Brno 2007, 76: 231-236.

The objective of the present work was to study the serological status and epidemiological situation of porcine teschovirus 1 (PTV-1) on swine farms in different Lithuanian regions by using virus neutralization test and virus isolation.

Clinical, epidemiological, serological and virological examinations were performed for the diagnosis of Teschen disease (porcine enterovirus encephalomyelitis, TE). Swine blood serum samples $(n=1680)$ were collected on 28 farms $(60$ samples per farm) of 8 regions in 2003 . For virus isolation 29 samples of pathological material were taken from the brains of pigs ( 2 - 4 months of age) that died suddenly on seven swine farms in five regions.

Epidemiological and clinical examination revealed no signs of porcine enterovirus encephalomyelitis on 32 Lithuanian swine farms. PTV-1 was not isolated and identified in the PK-15 cell culture. Antibodies against PTV-1, detected by using VNT, were found on all investigated farms and in all age groups. Negative serum $(2.3 \%, 39$ from 1680$)$ samples were found in $15.5 \%$ (16 from 103) of 2-4-month-old pigs and in 4.7\% (23 from 494) of 4-6-month-old ones. The positive serological and negative epidemiological, clinical and virological results suggest that less virulent or avirulent PTV-1 strains were spread on Lithuanian swine farms.
\end{abstract}

Teschen disease, porcine enterovirus encephalomyelitis

Porcine teschovirus 1 (PTV-1), previously called porcine enterovirus (PEV) serotype 1 is a causative agent of encephalomyelitis in pigs. Earlier the illness with PTV-1 (precisely PEV-1) was called Teschen or Talfan disease. Teschen disease (TeD) was reported for the first time near Teschen in Czechoslovakia over 75 years ago. It was described as a polioencephalomyelitis with a high mortality. Talfan disease (TaD) is a milder form of polioencephalomyelitis caused by serologically related but less virulent strains of PTV-1. Polioencephalomyelitis, but not $\mathrm{TeD}$ and $\mathrm{TaD}$, can be caused by other PTV serotypes and viruses also (Derbyshire 1999).

PEVs were described as causative agents of severe and mild neurological disorders, reproductive failure, pneumonia, diarrhoea, and dermal lesions in swine (Zell et al. 2001). PEVs have been divided into 11 serotypes (PEV-1 to - 11) based upon the virus neutralization test (VNT). Based on indicators such as cytopathic effect (CPE), replication properties in various host cell lines, and serological assays, the PEVs were divided into three CPE groups: I - serotypes 1 - 7 and 11 - 13; II - serotype 8; III - serotypes 9 - 10 (Know le s et al. 1980). Moreover, two new serotypes were identified in Germany (Auerbach et al. 1994). However, lately the results of phylogenetic analyses have allowed the reclassification of PEV. The amino acid identity level showed that porcine enteroviruses are distinct from each other within picornavirus taxonomy ( $\mathrm{Kaku}$ et al. 2001). According to the latest classification the proposed genus Teschovirus in Picornaviridae family contains one species, Porcine teschovirus, which is comprised of 11 serotypes, porcine teschovirus 1 (PTV-1) to 11 (Carter et al. 2004). These viruses formerly belonged to the genus enterovirus and were known as porcine enterovirus 1 to 7 and 11 to 13 (Krumbholz et al. 
2003). However, in the OIE Manual of Diagnostic Tests and Vaccines for Terrestrial Animals teschovirus encephalomyelitis (TE) is still called enterovirus encephalomyelitis (previously Teschen/Talfan diseases). So the terminology is misleading until now (O.I.E. 2000). PTVs are widely distributed in domestic pigs and wild boar and their infections are in most cases of subclinical nature (Fenner et al. 1993). PTVs usually do not cause heavy economic losses, even though nervous disorders called TeD spread as an epidemic in most European countries in the 1940s and 1950s. The condition was initially observed in Czechoslovakia in 1929 (Nardelli et al. 1993). Subsequently, a less severe clinical syndrome occurred almost exclusively, firstly described in the United Kingdom and termed TaD (Harding and Done 1957). TeD - TaD was causally connected with infections by strains of PTV-1. More recently, other serotypes have also been isolated from pigs with signs of polioencephalomyelitis, which were associated with high morbidity and mortality (Appel et al. 1995). However, no serological or molecular markers for differentiation of PTV strains corresponding to their virulence are available so far. Diagnosis of PTV is currently ascertained by identification of the agent in cell culture followed by VNT or complement fixation test (Knowles et al. 1980). In the course of TE, the virus propagates in the CNS, causing a non-suppurative encephalomyelitis with associated degeneration of motor ganglion cells. The disease is most commonly seen in suckling or weaned pigs, in which it causes fever, anorexia, ataxia, leg paralysis and convulsions. Small amounts of virus are present in faeces for a long time after clinical recovery, so that convalescent animals become a continuing source of infection (O.I.E. 2000). In Lithuania the serosurvey of swine farms has never been done with respect to TE so far.

Therefore the objective of the present work was to investigate the serological status and epidemiological situation of porcine teschovirus 1 (enterovirus encephalomyelitis) on swine farms in different Lithuanian regions by using virus neutralization test and virus isolation.

\section{Materials and Methods}

\section{Collection of samples}

A total of 1680 swine serum samples (60 samples per farm) were collected during the year 2003 at 28 swine farms from 22 Lithuanian districts. Samples were taken from pigs of various age groups, but not from all age groups. For virus isolation 29 brain samples were taken of 2 - 4-month-old pigs that died suddenly on seven swine farms from five Lithuanian regions.

\footnotetext{
Virus neutralization test

VNT was performed on 96 well/flat tissue culture test plates (TPP, Switzerland) in PK-15 cell culture. All swine sera were inactivated for $30 \mathrm{~min}$ at $56^{\circ} \mathrm{C}$ and diluted in MEM (HyClone, USA) cell culture medium with $10 \%$ of foetal bovine serum (HyClone, USA) from $1 / 2$ to $1 / 256$, four wells per dilution, 50 $\mu$ l per well. PTV-1 ("Gubkin"strain, FGU VGNKI, Russian Federation) was used as a stock virus (100 TCID $50150 \mu 1)$. PTV-1 "Gubkin" strain is registered by All-Russia State Scientific Research Institute for Monitoring, Standardisation and Certification of Veterinary Preparations (No. 185-/15-1, 03.03.2003). This virus strain belongs to All-Russia State collection of microorganism strains. It is stored and used for production of vaccine against porcine encephalomyelitis by NARVAC (Russian Federation) also. The "Gubkin" strain is antigenically analogous to the "Talfan" strain.

Incubation was performed at $37^{\circ} \mathrm{C}$ in a $\mathrm{CO}_{2}$ atmosphere for 3 days. The positive test results in $1 / 8$ or higher serum dilution were detected according to PTV-1 initiated CPE.

Virus isolation

Virological investigation was performed in PK-15 cell culture in 6 well/round tissue culture test plates (TPP, Switzerland). After centrifugation $0.3 \mathrm{ml}$ of $10 \%$ brain samples in MEM cell culture medium was used for inoculation of 3 days monolayer PK- 15 tissue culture. Incubation was done with $3.3 \mathrm{ml} \mathrm{MEM}$ (with $10 \%$ of foetal bovine serum at $37^{\circ} \mathrm{C}$ in a $5 \% \mathrm{CO}_{2}$ atmosphere) for 4 days. After that cell culture was examined for CPE detection. For the second passage freezing and defrost cell culture was inoculated again. A total of 4 passages were performed to isolate the virus from brain samples in PK-15 cell culture.
}

Statistical investigation

Statistical analysis was performed using a statistical program GraphPad Prism ${ }^{\circledR}$ (C) 1994 - 1999 by GraphPad Software). Mean (M), standard error of the mean (SEM), standard deviation (SD), $P$ value and significance were calculated. 


\section{Results}

The analysis of epidemiological and clinical investigations on all 28 swine farms (in 22 Lithuanian districts) showed no symptoms of TE.

The serum sample examination indicated (Table 1) that most of the samples (1641 out of 1680) were PTV-1 Ab positive. In Marijampole, Taurage, Telsiai, Utena and Vilnius regions all 720 samples were positive, from them 121 samples with a high - $1 / 64\left(6 \log _{2}\right)$ - PTV-1 Ab titre. $1 / 4\left(2 \log _{2}\right)$ PTV-1 Ab titre was detected in 1, 16 and 22 serum samples from pig farms of Panevezys, Klaipeda and Siauliai regions, respectively. That comprised only $2.3 \%$ of all investigated samples.

Table 1. Results of serosurvey for PTV-1 Ab by VNT in Lithuania in 2003

\begin{tabular}{|c|c|c|c|c|c|c|c|c|c|}
\hline \multirow{3}{*}{ Region } & \multirow{3}{*}{$\begin{array}{l}\text { Number } \\
\text { of farms }\end{array}$} & \multirow{3}{*}{$\begin{array}{l}\text { Sample } \\
\text { No. }\end{array}$} & \multirow{2}{*}{\multicolumn{5}{|c|}{ The numbers of serum samples }} & \multicolumn{2}{|c|}{$\begin{array}{c}\text { The number of } \\
\text { positive samples }\end{array}$} \\
\hline & & & & & & & & \multirow{2}{*}{$\mathrm{N}$} & \multirow{2}{*}{$\%$} \\
\hline & & & $1 / 4$ & $1 / 8$ & $1 / 16$ & $1 / 32$ & $1 / 64$ & & \\
\hline Alytus & 1 & $\mathrm{~N} / \mathrm{D}$ & - & - & - & - & - & - & - \\
\hline Kaunas & 3 & $\mathrm{~N} / \mathrm{D}$ & - & - & - & - & - & - & - \\
\hline Klaipeda & 2 & 120 & 16 & 45 & 36 & 15 & 8 & 104 & 86.7 \\
\hline Marijampole & 3 & 180 & 0 & 10 & 74 & 59 & 37 & 180 & 100.0 \\
\hline Panevezys & 6 & 360 & 1 & 52 & 97 & 123 & 87 & 359 & 99.7 \\
\hline Siauliai & 8 & 480 & 22 & 93 & 151 & 152 & 62 & 458 & 95.4 \\
\hline Taurage & 2 & 120 & 0 & 31 & 37 & 35 & 17 & 120 & 100.0 \\
\hline Telsiai & 1 & 60 & 0 & 0 & 8 & 31 & 21 & 60 & 100.0 \\
\hline Utena & 2 & 120 & 0 & 7 & 45 & 46 & 22 & 120 & 100.0 \\
\hline Vilnius & 4 & 240 & 0 & 44 & 103 & 69 & 24 & 240 & 100.0 \\
\hline Total & 32 & 1680 & 39 & 282 & 551 & 530 & 278 & 1641 & 97.7 \\
\hline
\end{tabular}

Negative titre $1 / 4\left(2 \log _{2}\right)$ was detected in $15.5 \%$ sera samples (16 from 103) of the 2 - 4month-old pigs and $4.7 \%$ cases ( 23 from 494) of 4 - 6-month-old ones.

PTV-1 Ab titre $1 / 8\left(3 \log _{2}\right)$ was detected in 282 serum samples (16.8\%), respectively $1 / 16$ $\left(4 \log _{2}\right)-551(32.8 \%), 1 / 32\left(5 \log _{2}\right)-530(31.6 \%)$ and $1 / 64\left(6 \log _{2}\right)-278$ (16.5\%) (Fig. 1).

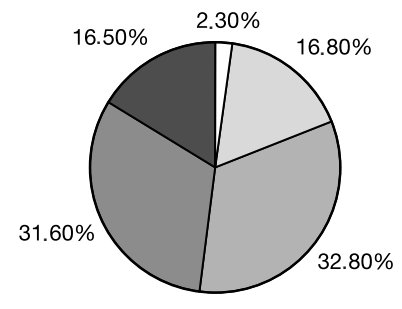

$\square 2 \log 2 \square 3 \log 2 \square 4 \log 2 \square 5 \log 2 \square 6 \log 2$

Fig. 1. Distribution of PTV-1 Ab titres in pig serum samples by VNT

The statistical analysis of serosurvey results in different pig groups (Table 2) indicated a level of Ab titres in sows in all Lithuanian regions. A total of 730 serum samples of sows were collected from 22 swine farms. The means of PTV-1 Ab titres were from $4.3 \log _{2}$ (Klaipeda region swine farm) to $5.5 \log _{2}$ (Telsiai region swine farm). The variation of SD 
index was $0.7-1.0 \log _{2}$ in range and indicated a very wide distribution of Ab titres in all sow groups.

The analysis of serum samples of 2-4-month-old pigs showed that PTV-1 Ab titres were at a lower level than in the sow groups. The means of PTV-1 Ab titres were from $3.0 \log _{2}$ (Klaipeda region swine farm) to $4.6 \log _{2}$ (Utena region swine farm). The variation of SD index was within $0.2-0.9 \log _{2}$. The steadiest statistical results were in 4-6-month-old pig groups on all Lithuanian farms. The titre means of $4.4-4.5 \log _{2}$ were identified in all regions, except the Vilnius region, where the mean of PTV-1 Ab titres in serum samples was $3.9 \log _{2}$. That was the second largest investigated pig group (494 samples), but the variation of SD index was wider than in sow groups and was within $0.7-1.1 \log _{2}$. All statistical calculations were reliable.

Table 2. Statistical analysis of PTV-1 Ab titres in different pig groups

\begin{tabular}{|c|c|c|c|c|c|c|}
\hline Region & $\begin{array}{l}\text { Number } \\
\text { of farms }\end{array}$ & Pigs & $\mathrm{n}$ & $\begin{array}{c}\mathrm{M} \\
\left(\log _{2}\right)\end{array}$ & $\begin{array}{c}\mathrm{SD} \\
\left(\log _{2}\right)\end{array}$ & $\begin{array}{l}\text { SEM } \\
\left(\log _{2}\right)\end{array}$ \\
\hline \multirow[t]{3}{*}{ Klaipeda } & 1 & \multirow{3}{*}{$\begin{array}{c}\text { Sows } \\
\text { 2-4-month-old pigs } \\
\text { 4-6-month-old pigs }\end{array}$} & 52 & 4.3 & 1.0 & 0.1 \\
\hline & 1 & & 60 & 3.0 & 0.7 & 0.1 \\
\hline & 1 & & 8 & 4.5 & 0.9 & 0.3 \\
\hline \multirow[t]{3}{*}{ Marijampole } & 2 & \multirow{3}{*}{$\begin{array}{c}\text { Sows } \\
\text { 2-4-month-old pigs } \\
\text { 4-6-month-old pigs }\end{array}$} & 80 & 4.8 & 0.7 & 0.1 \\
\hline & 2 & & 13 & 3.7 & 0.2 & 0.1 \\
\hline & 3 & & 87 & 4.5 & 0.7 & 0.1 \\
\hline \multirow[t]{2}{*}{ Panevezys } & 6 & \multirow{2}{*}{$\begin{array}{c}\text { Sows } \\
\text { 4-6-month-old pigs }\end{array}$} & 274 & 4.7 & 0.8 & 0.1 \\
\hline & 3 & & 86 & 4.4 & 0.9 & 0.2 \\
\hline \multirow[t]{2}{*}{ Siauliai } & 6 & \multirow{2}{*}{$\begin{array}{c}\text { Sows } \\
\text { 4-6-month-old pigs }\end{array}$} & 254 & 4.4 & 0.8 & 0.1 \\
\hline & 5 & & 226 & 4.4 & 0.7 & 0.1 \\
\hline \multirow[t]{2}{*}{ Taurage } & 2 & \multirow{2}{*}{$\begin{array}{c}\text { Sows } \\
\text { 4-6-month-old pigs } \\
\end{array}$} & 101 & 4.4 & 1.0 & 0.2 \\
\hline & 1 & & 19 & 4.5 & 1.1 & 0.2 \\
\hline Telsiai & 1 & Sows & 60 & 5.2 & 0.7 & 0.1 \\
\hline \multirow[t]{3}{*}{ Utena } & 2 & \multirow{3}{*}{$\begin{array}{l}\text { Sows } \\
\text { 2-4-month-old pigs } \\
\text { 4-6-month-old pigs }\end{array}$} & 54 & 4.8 & 0.7 & 0.2 \\
\hline & 2 & & 30 & 4.6 & 0.9 & 0.2 \\
\hline & 2 & & 36 & 4.4 & 0.8 & 0.2 \\
\hline \multirow[t]{3}{*}{ Vilnius } & 2 & \multirow{3}{*}{$\begin{array}{c}\text { Sows } \\
\text { 0-2-month-old piglets } \\
\text { 4-6-month-old pigs }\end{array}$} & 109 & 4.6 & 0.8 & 0.1 \\
\hline & 3 & & 99 & 4.0 & 0.7 & 0.1 \\
\hline & 1 & & 32 & 3.9 & 0.8 & 0.1 \\
\hline
\end{tabular}

For virus isolation 29 samples of pathological material were taken from the brains of pigs that died suddenly (they were 2-4 months old). Brain samples were collected on seven farms in five regions. Virological examination showed that all 29 brain samples were negative with respect to PTV-1.

\section{Discussion}

TE investigation was performed according to the O.I.E. recommendation. The most suitable methods for diagnosis are demonstration of characteristic post-mortem microscopic lesions in the central nervous system of affected pigs, isolation and subsequent identification of PTV-1, and demonstration of specific antibodies (O.I.E. 2000). TE serological investigation in Lithuania indicated a high seroprevalence of PTV-1 Ab in all groups of tested pigs. All sow serum samples were positive with $\mathrm{Ab}$ titres from 4 to $6 \log _{2}$. In case of TeD specific antibody titres can reach $7-9 \log _{2}$ (Mayr et al. 1984). Ab titres lower than $2 \log _{2}$ (negative) were identified in some serum samples of 2-4-month-old and 4-6-month- 
old pigs. However, these titres can also be due to maternal immunity. Some pigs of such age groups may have maternal antibodies against porcine parvovirus (Paul et al. 1982).

TE epidemiological and clinical investigations were negative, the same as virus isolation in the PK-15 cell culture from tested brain samples. The high Ab titres can be associated with a PTV-1 virus persistence. PTV normally spreads between piglets shortly after weaning when maternally derived $\mathrm{Ab}$ are withdrawn and individuals from several litters are mixed together. Adults rarely excrete the virus, but have a high Ab level. On the other hand, serological investigation by using VNT can be complicated due to the significant crossreactivity of PTV-specific antibodies (Zell et al. 2001). So the serological investigation can demonstrate antibodies against PTV-1 or other non- and less-pathogenic strains and serotypes of PTV. Another aspect concerning evolutionary changes of teschoviruses is the observation that the virulence of these viruses is gradually changing. The manifestation index of severe polioencephalomyelitis decreased and the highly virulent Teschen strains were replaced by less virulent Talfan (PTV) strains (Fenner et al. 1993; Harding 1957). Today, PTV-1 is still frequently isolated from the faeces, tonsils, and other non-neural organs of clinically unaffected pigs. Moreover, other serotypes than PTV-1 are increasingly identified to be the cause of neurological disorders in swine (Auerbach et al. 1994). Determination of whether this observation reflects changes of virus prevalence or is the result of improved methods of virus detection (Zell et al. 2000) and virus isolation awaits further investigations (Zell et al. 2001). So the researchers can diagnose (i) infections with PTV which may exclude infections with classical swine fever virus, pseudorabies virus, porcine parvovirus and porcine respiratory and reproductive syndrome virus and (ii) infections with viruses of CPE group III (PEV-9, PEV-10) which may exclude infections with the food-and-mouth disease virus (Zell et al. 2000).

The investigation of PTV by VNT in a single serum samples indicate the pig's serological status only. It is possible to suspect the disease after repeated examination of serum samples: the first one has to be done during the clinical manifestation period and the second after 2025 days. For that purpose VNT and ELISA methods could be used (Hubschle et al. 1983). In that case the diagnosis could be confirmed after detection of a fourfold and higher PTV $\mathrm{Ab}$ titres in a second sample and positive virus isolation/identification in cell culture (Nardelli et al. 1993; Pogranichniy et al. 2003).

TE serological investigation indicated a high level of Ab in Lithuanian pigs, but was negative in epidemiological, clinical and virus isolation survey.

In conclusion, the epidemiological and clinical investigation found no signs of TE on 32 Lithuanian swine farms. PTV-1 was not isolated and identified in the PK-15 cell culture. PTV-1 Ab, detected by using VNT, was found on all investigated farms and in all pig age groups. Negative serum $\left(2.3 \%, 39\right.$ from 1680) samples (2 $\log _{2}$ titres) were found in $15.5 \%$ serum samples (16 from 103) of 2-4-month-old pigs and 4.7\% (23 from 494) in 4-6- monthold ones. The $95-100 \%$ positive serological and negative epidemiological, clinical and virological analyses suggest that less virulent or avirulent PTV-1 strains were spread on Lithuanian swine farms.

\section{Séroprevalence protilátek proti viru Těšínské nemoci prasat v Litvě}

Cílem této práce bylo studovat porcinní Enterovirus 1 (PTV-1), jeho séroprevalenci a epidemiologickou situaci $\mathrm{v}$ chovech prasat $\mathrm{v}$ různých regionech Litvy s využitím virus neutralizačního testu a přímé izolace viru. V rámci diagnostiky Těšínské choroby prasat (porcinní enterovirová encefalomyelitida, TE) byla provedena klinická, epidemiologická, sérologická vyšetření a virologické testy. V roce 2003 byly v osmi regionech na 28 farmách odebrány vzorky séra $(n=1680), 60$ vzorků z každé farmy. K izolaci viru bylo odebráno 29 vzorků patologického materiálu z mozků prasat (ve věku 2-4 měsíce), která náhle uhy- 
nula na sedmi farmách v pěti regionech. Epidemiologickými a klinickými testy nebyly odhaleny žádné známky infekce virem porcinní encefalomyelitidy na žádné z 32 litevských farem. Na buněčné kultuře PK-15 nebyl PTV-1 ani izolován ani identifikován. Na všech vyšetřovaných farmách a u zvířat všech věkových skupin byly s využitím VNT detekovány protilátky proti PTV-1 viru. Bylo zjištěno 15,5 \% negativních vzorků séra (16 ze 103) u prasat ve věku 2-4 měsíce a 4,7 \% (23 ze 494) u prasat ve věku 4-6 měsíců. Pozitivní sérologické a negativní epidemiologické, klinické a virologické výsledky testů naznačují, že na litevských farmách jsou rozšířeny spíše málo virulentní či avirulentní kmeny PTV- 1.

\section{References}

APPEL G, STEINHAGEN P, OHLINGER VF, EWALD C 1995: Enzephalomyelopathie bei Sauen und Mastschweinen infolge einer Infektion mit porzinem Enterovirus (PEV). Tieraerztl Umsch 50: 326-336

AUERBACH J, PRAGER D, NEUHAUS S, LOSS U, WITTE KH 1994: Grouping of porcine entoroviruses by indirect immunofluorescence and description of two new serotypes. Zbl Vet Med B 41: 277-282

CARTER GR, WISE DJ, FLORES EF (Eds) 2004: International Veterinary Information Service, Ithaca NY (www.ivis.org), A3401.1204.

DERBYSHIRE JB 1999: Enterovirus. In: STRAW BE, D’ALLAIRE S, MENGELING WL, TAYLOR DJ (Eds): Diseases of Swine. $8^{\text {th }}$ edition. Iowa State University Press, Ames, USA, pp. 145-150

FENNER FJ, GIBBS GJ, MURPHY FA, ROTT R, STUDDERT MJ, WHITE DD 1993: Porcine enteroviruses. In: Vet Virol Acad Press, San Diego, pp. 416-419

HARDING JDJ, DONE JT 1957: A transmissible polioencephalomyelitis in pigs (Talfan disease). Vet Rec 69: 2-8

HAHNEFELD H, HAHNEFELD E, WITTIG W 1965: Talfan disease der Schweine in Deutschland. I. Mitteilung: Isolierung und Charakterisierung von Teschenvirus Subtyp Talfan bei Saugferkeln im Bezirk Dresden. Arch Exp Vet Med 12: 185-218

HUBSCHLE OJ, RAJANARISON I, KOKO M, RAKOTONDRAMARY E, RASIOFOMANANA P 1983: ELISA for testing swine sera for antibodies against Teschen virus. Deut Tierarztl Wochenschr 90: 86-88

KAKU Y, SARAI A, MURAKAMI Y 2001: Genetic reclassification of porcine enteroviruses. J Gen Virol 82: 417-424

KNOWLES NJ, BUCKLEY LS, PEREIRA HG 1979: Classification of porcine enteroviruses by antigenic analysis and cytopathic effects in tissue culture: description of 3 new serotypes. Arch Virol 62: 201-208

KNOWLES NJ, BUCKLEY LS 1980: Differentiation of porcine enterovirus serotype by complement fixation. Res Vet Sci 29: 113- 115

KRUMBHOLZ A, WURM R, SCHECK O, BIRCH-HIRSCHFELD E, EGERER R, HENKE A, WUTZLER P, ZELL R 2003: Detection of porcine teschoviruses and enteroviruses by Light Cycler real-time PCR. J Virol Meth 113: $51-63$

MAYR A, EISSNER G, MAYR-BIBRACK A 1984: Teschener Krankheit der Schweine. In: MAYER A, EISSNER G, MAYER-BIBRACK A (Eds.): Handbuch der Schutzimpfungen in der Tiermedizin. Berlin-und Hamburg, Verlag Paul Parey, pp. 407-417

NARDELLI S, FARINA L, SELLI L, PARPAIOLA R, ZUIN A 1993: Research on the presence of porcine enterovirus serotype 1 in north-eastern Italy. Zentbl Vet Med B 40: 190-196

O.I.E. 2000: Manual of Standards for Diagnostic Tests and Vaccines. Part 2, Section 2.6., Chapter 2.6.3. Enterovirus encephalomyelitis (previously Teschen/Talfan diseases)

PAUL PS, MENGELING WL, PIRTLE EC 1982: Duration and biological half-life of passively acquired colostral antibodies to porcine parvovirus. Am J Vet Res 43: 1376-1379

POGRANICHNIY RM, JANKE BH, GILLESPIE TG, YOON KJ 2003: A prolonged outbreak of polioencephalomyelitis due to infection with a group I porcine enterovirus. J Vet Diagn Invest 15 (2): 191-194

ZELL R, DAUBER M, KRUMBHOLZ A, HENKE A, BIRCH-HIRSCHFELD E, STELZNER A, PRAGER D, WURM R 2001: Porcine teschoviruses comprise at least eleven distinct serotypes: molecular and evolutionary aspects. J Virol 75): 1620-1631

ZELL R, KRUMBHOLZ A, HENKE A, BIRCH-HIRSCHFELD E, STELZNER A, DOHERTY M, HOEY E, DAUBER M, PRAGER D, WURM R 2000: Detection of porcine enteroviruses by nRT-PCR: differentiation of CPE groups I-III with specific primer sets. J Virol Meth 88: 205-218 